\title{
Analysis of delay factors and their effects on construction projects
}

\author{
Yahya Rashid ${ }^{\mathbf{a}^{*}}$
}

${ }^{a}$ Prince Sattam bin Abdulaziz University, College of Engineering, Mechanical Engineering Dept., Al-Kharj, Saudi Arabia

\begin{tabular}{l}
\hline C H R O N I C L E \\
\hline Article history: \\
Received: October 26, 2019 \\
Received in revised format: No- \\
vember 27 2019 \\
Accepted: November 27, 2019 \\
Available online: \\
November 27, 2019 \\
\hline Keywords: \\
Construction projects \\
Delay \\
Causes \\
Contractor \\
\hline
\end{tabular}
\section{A B S T R A C T}

\begin{abstract}
Construction projects more often are facing with unpredictable delays and it is one of the biggest challenges to mitigate such delays. The aim of the present study is to explore causes and effects of delays on construction projects executed in Pakistan. Empirical methodology is used and the data is collected from 37 construction companies and questionnaires are distributed to 172 professionals. Various statistical tools are applied such as multiple regression to analyze the data. The finding of this analysis show that significant causes of delay factors are associated and ordered as contractor, client, consultant, material and equipment respectively; however, there is not any effect of delay on factors such as, labor and general environment. Finally, it is analyzed that construction projects delay lead considerably to project time overrun, cost overrun, project abandonment, and litigation. All these factors can bring projects on great risk. The analysis of the study gave considerable understandings to stakeholders of construction projects in order to formulate strategies to overcome delay and their impacts.
\end{abstract}

\section{Introduction}

In project management scope, time and performance have strong relationships with each other. Changes occur in these areas have strong impacts on project performance (Jaafari, 2001; Nilashi et al., 2015). Delay is one of the important factors influencing on the construction projects because it is directly linked with increase in the project cost. According to Eastman (2018) and Doloi (2012), delay is defined as "event or act that increases time needed to execute or complete contract work demonstrates itself as further delays of work". It is valuable for all stakeholders, like consultant, contractor, client, of construction project to complete it on time (El-Razek, 2008; Al-Kharashi \& Skitmore, 2009; Rahsid et al., 2013). Therefore, it is essential to identify delay factors of construction projects in general and for specific country in particular. Delay is considered costly for both owner and construction firms related with time-overrun, negotiations, cost overrun, and disputes like court cases. Numerous studies in various countries are conducted on delay factors of construction projects like: investigation of Malaysian construction industry (Sambasivan, 2007), knowledge and effects on construction projects in Taiwan (Chou et al., 2012), and a case study of Chinese contractor (Deng et al., 2014). However, few studies are carried out in case of Pakistan. An attempt is made (Shaikh, 2010) to find the factors related with delay-causes in construction projects of Pakistan. However, study provided theoretical insights about this phenomenon. Similarly, investigation is conducted in a study (Haseeb, 2011), and explored the causes behind the delay of construction projects in Pakistan. Nevertheless, they did not measure the relationship related with cause and effect of the construction projects. In another study (Rashid, 2013), causes of delays on construction projects of Pakistan are evaluated. Detrimental changes in construction project and their effects were analyzed (Maqbool \& Rashid, 2017). Yet, this study focused the parameters related with changes in construction projects. This empirical study contributes, verifies, and enhances the existing knowledge of project delays by analyzing antecedents and outcomes of delay through cause and effect relationship on construction projects of Pakistan.

\footnotetext{
* Corresponding author.

E-mail address: y rashid@yahoo.com (Y. Rashid) 


\section{Literature review}

Many researchers have discussed the delaying factors in construction industry in numerous ways. Some researchers emphasized the main delaying factors and several project categories, while other studies debated ways of analyzing delay and suggested methods to lessen these delays. In fact, such delays seriously affects on project performance.

\subsection{Causes of Delays}

Baldwin (1971) conducted a study to determine the delaying factors related with construction industry of America. Construction industry is facing project completion delays all over the world due to various reasons. The major delaying factors in large building projects is shown in study by Assaf (2006). Yang (2010) explored several causes of delay both in planning as well as in design phase of construction projects. In major construction projects, problems causing delays are discussed in studies of Wang (2015; Sweis, 2008; Lo et al., 2006). It was reported that delays mostly occur because of improper management of several factors that are related to key stakeholder such as client, contractor, consultants, labor and equipment, and material required for projects. For instance, factors, causing delays due to contract with contractors in Indonesia was discussed by Mohammed et al. (2019). Above-mentioned causes of project delays have impacts on project cost overruns, time overruns and such problems occur frequently in construction industries.

\subsection{Effects of Delays}

The delays in construction projects influence on cost, time, or scope of project. According to Zhu (2005), cost overrun or escalations is due to the difference of the assigned budgeted cost and the actual cost of a project. Moreover, it is reported that the utmost common reason of delay in construction industry of Nigeria is cost overrun (Aibinu, 2002). Shehu (2014) debated about cost overrun in Malaysian industry. Arditi (2007) discussed about the methods of resolving construction claims.

\section{Methodology}

\subsection{Research Design}

Hypotheses are developed based on cause and effect factors of construction projects:

Hypothesis-1: Factors related with client have significant effects on completion of project.

Hypothesis-2: Factors related with contractor have substantial influences on project completion.

Hypothesis-3: Factors related with consultant have substantial influences on project completion.

Hypothesis-4: Chances of delay in project completion increase due to shortage of material

Hypothesis-5: Unavailability of modern equipment escalates the probabilities of delay in project completion.

Hypothesis-6: Lacking skilled labor escalates the probability of delay in project completion.

Hypothesis-7: General environmental conditions (e.g. political stability, Government policies, and weather) have substantial influence on project completion.

Hypothesis-8: Construction project delay results in time overrun.

Hypothesis-9: Construction project delay escalates project cost.

Hypothesis-10: Probabilities of litigation against firm increases due to delay in construction projects.

Hypothesis-11: Delay in the construction project results in project abandonment.

By using empirical perspective (Maqbool et al., 2018) and survey approach, it is possible to obtain views from the professionals of firms.

\subsection{Research Model}

Based on the suggested eleven hypotheses, a research model is developed for testing and analyzing these factors (See Fig. 1.)

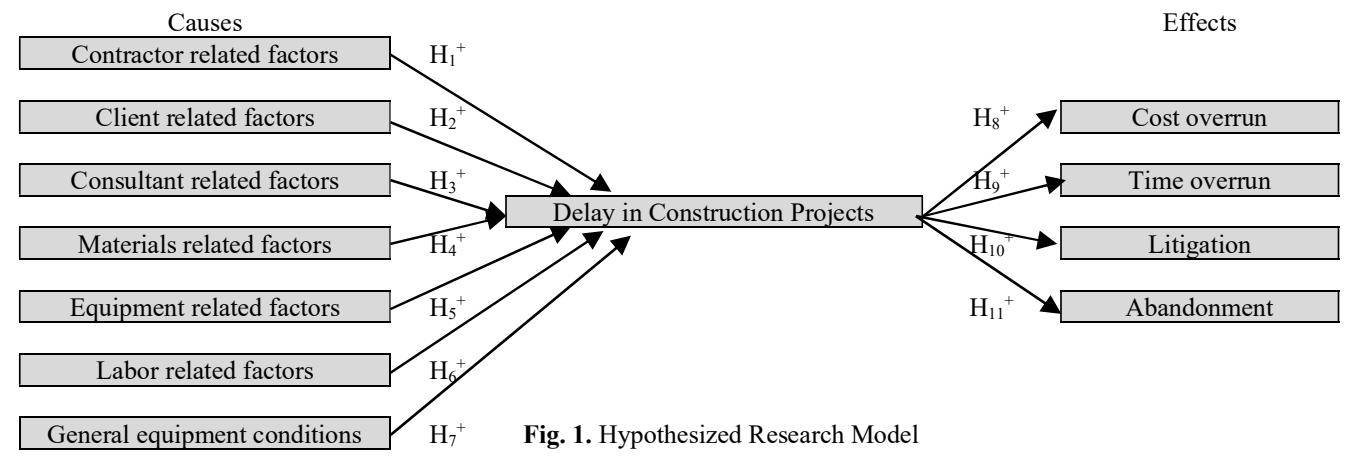




\subsection{Questionnaire Development}

In this study, seven factors related with causes of delay on construction projects and four factors related with effects of delays are studied, as shown in Fig. 1. Causes of delay factors are related with contractors, client, consultant, material, equipment, labor, and general. Effects of delay factors are related with time overrun, litigation, cost overrun, and abandonment.

Factors and their measures: Got construction companies list from Pakistan Engineering Council. Selected randomly thirtyseven companies from Punjab. For evaluation of contractor, client, and consultant related factors, the scale of Al-Khalil (1999) was used with adjustment and for rest of the factors the scale of Wei (2010) was used with some modifications. After pilot study, few questionnaires were removed for final survey. Questionnaires considered in this research are shown in the attached appendix. Data was collected and screened based on any missing values. A sample of 172 questionnaires found completed in all respect, and used in this study.

\section{Results and discussion}

Validity and reliability analysis are performed. Descriptive analysis and hypotheses testing are performed using Structural Equation Model (SEM).

\subsection{Hypothesis testing}

SEM is used to determine causal relationship between dependent and independent variables for eleven developed hypotheses. Model fitness indices of SEM is shown in Table 1. The calculated fitness indices are found within acceptable range. For instance, the ratio of relative chi square is 2.97. It represents model fitness when the value to be determined is below the upper limit of 5. In addition, the research about model fitness value should be considered good, which indicates relative chi-square value with upper limit of 5 and lower as 2 (Marsh, 1985). The values of Normed Fit Index (NFI), Comparative Fit Index (CFI) and Goodness of Fit Index (GFI) are found 0.92, 0.94, and 0.91 respectively. In addition, when these values are closer to 1 , the fitness of particular model is superior.

\section{Table 1}

Fitness Indicators

\begin{tabular}{lllllll}
\hline CMIN & DF & CMIN & GFI & NFI & CFI & RMSEA \\
\hline 97.97 & 33 & 2.96 & 0.91 & 0.92 & 0.94 & 0.10 \\
\hline
\end{tabular}

Multiple linear regression is applied to test the hypothesis. Table 2 shows the relation between the causes of delay factors and project delay, in construction projects. To perform analysis the most frequently used statistical technique is regression. Regression equation is shown below:

Delay $=-0.919 \beta_{0}+0.364 \beta_{1}^{* *}+0.285 \beta_{2}^{*}+0.246 \beta_{3}^{* * *}+0.224 \beta_{4} * * *+0.192 \beta_{5} * *+0.198 \beta_{6}-0.073 \beta_{7}+€$

Table 2

Multiple linear regression

\begin{tabular}{|c|c|c|c|c|c|c|}
\hline \multirow[t]{2}{*}{ Model } & \multicolumn{2}{|c|}{ Un-standardized Coefficients } & \multirow[t]{2}{*}{$\mathrm{T}$} & \multirow[t]{2}{*}{ Sig } & \multicolumn{2}{|c|}{ Collinearity Statistics } \\
\hline & $\mathrm{B}$ & Std. Error & & & Tolerance & VIF \\
\hline (Constant) & -919 & .846 & -1.087 & .279 & & \\
\hline Contractor Related Factors & .364 & .163 & 2.2334 & .027 & .298 & 3.360 \\
\hline Client Related Factors & .285 & .156 & 1.828 & .069 & .204 & 4.901 \\
\hline Consultant Related Factors & .246 & .082 & 2.980 & .003 & .581 & 1.722 \\
\hline Material Related Factors & .224 & .077 & 2.892 & .004 & .626 & 1.596 \\
\hline Equipment Related Factors & , 192 & .085 & 2.268 & .025 & .483 & 2.071 \\
\hline Labor Related Factors & .198 & .136 & 1.451 & .149 & .373 & 2.679 \\
\hline General Factors & -.073 & .156 & -.456 & .642 & .215 & 4.656 \\
\hline
\end{tabular}

Adjusted $\mathrm{R}=0.42, \mathrm{~F}$-test value $=18.47, \mathrm{~F}$-test significance $=0.00$

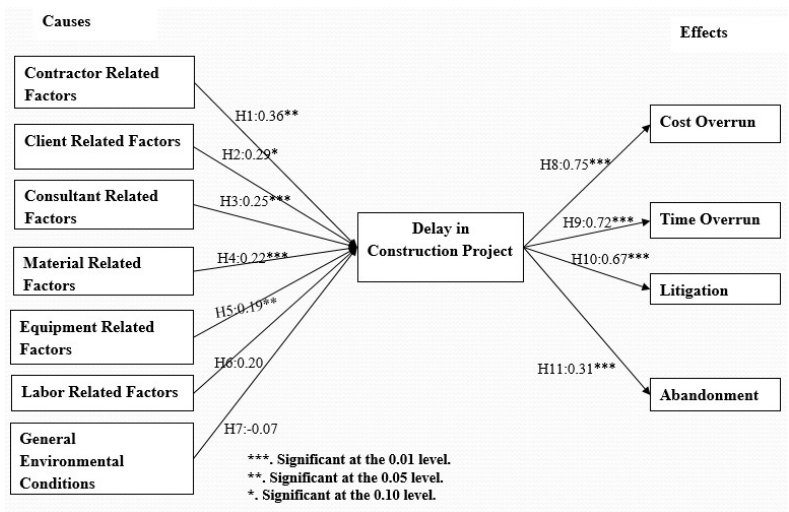

Fig. 2. Structural Equation Model 
Factors related with Contractor: The hypothesis-1 tests the link between "factors related with contractor" and delay of construction projects. The SEM outcomes are indicated in Fig. 2. In Table 3, analysis of this hypothesis is summarized. It is found that the contractor related factors have positive effects on the delay, in project completion. Moreover, the $\beta$ value obtained is 0.36 which is significant at $95 \%$ level of confidence. Therefore, the hypothesis- 1 is accepted, which indicates that risks of error and rework lack of communication and coordination, complications in financing, insufficient work of contractor, improper implementation of construction methods have caused significant variance in project delay.

Factors related with Client: The second hypothesis is the relationship between "factors related with client" and delay in completion of the project. Moreover, the results $(\mathrm{p}=0.10)$ of regression model found significant. The $\beta$ value became 0.29 , which specifies moderately positive relationship between the two variables. It is determined that the "factors related with Client" like change in orders late payments, approving designs, poor communication, slow decision-making process have direct impacts on delay, in construction projects of Pakistan.

Factors related with Consultant: The relationship of 3rd hypothesis is between "Factors related with Consultant" and delay in projects is tested. The relationship found significantly positive $(\mathrm{p}=0.01)$. The $\beta$ value became 0.25 , which represents moderate impact of predictor variable on dependent variable. Therefore, the hypothesis 3 is also accepted.

Factors related with Material: The 4th hypothesis measures the effect of material factors on project delay. The analysis reveals that there is positively significant relationship between variables. The $\beta$ found as 0.22 . The findings report that material shortage, poor material quality, shortage of material, delay in delivery of material and procurement delay are the main causes of delay in projects.

\section{Table 3}

Hypothesis decision

\begin{tabular}{|c|c|c|c|c|}
\hline Hyp. No. & Independent Variable & Dependent Variable & Regression Co-efficient & Decision \\
\hline 1 & "Factors related to Contractor" & Delay & $0.36^{* *}$ & Accepted \\
\hline 2 & "Factors related to Client" & Delay & $0.29^{*}$ & Accepted \\
\hline 3 & "Factors related to Consultant" & Delay & $0.25 * * *$ & Accepted \\
\hline 4 & "“"Factors related to Material" & Delay & $0.22 * * *$ & Accepted \\
\hline 5 & "Factors related to Equipment" & Delay & $0.19^{* *}$ & Accepted \\
\hline 6 & "Factors related to Labor" & Delay & 0.20 & Rejected \\
\hline 7 & "General Factors" & Delay & -0.07 & Rejected \\
\hline 8 & "Delay" & Cost Overrun & $0.75^{* * *}$ & Accepted \\
\hline 9 & "Delay" & Time Overrun & $0.72 * * *$ & Accepted \\
\hline 10 & "Delay" & Litigation & $0.67 * * *$ & Accepted \\
\hline 11 & "Delay" & Abandonment & $0.31 * * *$ & Accepted \\
\hline
\end{tabular}

Factors related with Equipment: The analysis of hypothesis five revealed that equipment have positive significant effect on delay in construction projects. The value of $\beta$ found as 0.19 . The analysis explains that factors related with equipment have more delay of projects in small construction firms that may have investment issues to spend for mechanical equipment.

Factors related with Labor: The 6th hypothesis investigated the connection between "Factors related with labor" and delay in construction projects. The finding explores that there is no significant relationship between them; that is there the Labor Factors delay is nullified. There is no significant effect, which means rejection of the 6th hypothesis.

General factors: This hypothesis determines the connection between "General Factors" and "Delay". The analysis shows an insignificant relationship between these variables. The $\beta$ value became -0.07 , which clearly reveals the rejection of 7 th hypothesis.

Relationship of Delay and cost overrun: The investigation of the 8th hypothesis discloses that delay had a positive outcome on cost overrun. The P-value became 0.01 , which indicates that the relationship is positively significant between these two variables. In addition, the $\beta=0.75$ value suggested that such delays causes $75 \%$ of cost overruns.

Relationship of delay with time overrun: The analysis of this relationship reveals that delay has direct impact on time overruns in construction projects. The $0.01 \mathrm{p}$-value shows that the relationship is positively significant. The $\beta$ for these variables is 0.72 . These values elucidate that hypothesis 9 is accepted. This means, fair number of construction projects are having time overrun issues.

Relationship of Delay and litigation: The hypothesis 10 studies the effect of delay on litigation. The analysis of this hypothesis suggested that the relationship is significantly positive. The analysis outlines $0.01 \mathrm{p}$-value and $\beta$-value became 0.67 , which proposes acceptance of tenth hypothesis. 
Relationship of Delay and abandonment: The 11th hypothesis examines the connection between delay and abandonment. The analysis concludes that there exists a positive relationship between these variables, which has direct impact on project abandonment.

\subsection{Discussion}

This study focuses on several causes and their effects in delaying construction projects of Pakistan. Various statistical tools have been applied to evaluate the data. Out of seven delaying factors considered in this study, the contractor related factors (hypothesis-1) and factors related with client (hypothesis-2) have the most significant effects on the construction projects of Pakistan. The finding of this study about hypothesis-1, is aligned with the results of Odeh, (2002), who classified contractors as the main contributor for delay in construction projects. The outcomes of the research (Zaneldin, 2006) highlighted several reasons, such as financial problems of contractor, improper planning of contractor, unexperienced contractor are the main causes of delay in construction industry. The results of the second hypothesis is moderately aligned with Haseeb et al. (2011), who explored that delays caused by clients such as insufficient site information, deferral in submission of specifications, and late submission of drawings. It is found by Williams (2003) that in developed countries, it is common that clients depend on contractor services to cover the risk of damage and time.

The findings of 4th hypothesis is aligned with the research of Sambasivan (2007), who reported the fact that delivery and availability of material are amongst the critical factors in completion of construction projects on time. In case of fifth hypothesis, equipment breakdown, the finding partially is aligned with the research (Assaf, 2006; Mohamed et al., 2019) that highlight material shortage, operating skill, efficiency, and lack of high-tech equipment, are causing delay in such projects. The analysis of 6th hypothesis shows that the relationship between two variables is not significant. On contrary, few studies found significant relationship. However, such researches seldom used the approach of calculating SEM weights in order to find the impact of factors related with labor, on delay of construction projects. There could be several possibilities that can aggravate such as, labor shortage; however, in case of Pakistan plentiful labor can be found easily and at relatively lower cost for construction projects. Sambasivan (2007) reported that illegal labor caused delay of project in Malaysia. On the other hand, in case of Pakistan, negative consequences of illegal labor do not exist, as attaining labor for construction project is not an issue. In addition, the requirement of working permit for labor in Malaysia (which is not essential in case of Pakistan) could be another reason to slow down the progress of project completion. Therefore, the impact of labor force is not that significant in case of construction projects of Pakistan.

The hypothesis 7 determines an insignificant relationship between the variables. One of the facts is that general factors can have long list and diversity, which can lead to delay in construction projects. Some of the researches considered external factors as important predictor, like Assaf (2006) concluded that severe weather condition, as external factor, in Saudi Arabia is one of main predictors of construction project delays. However, the weather conditions in major cities of Pakistan is not that harsh and projects may be planned to avoid such conditions. The eight hypothesis has significant positive relationship. The time overrun mean value is found to be 3.61; which means that quite a number of projects are having time overrun issue. In a research by Odeh (2002), it was analyzed that the factors related with client generally responsible for construction projects time overruns. The analysis of hypothesis reveals that there is a strong relationship between delay and cost overruns. Aibinu (2002) concluded in his research on delays in construction projects and indicated overrun of budgets. Therefore, delay elevates the overall cost of project from the estimated cost. In addition, the activities like reworking in projects require spending money and time, which directly contributes in project cost. Hypothesis 10 has significant positive relationship between variables. In a study by Arditi (2006) it has been highlighted that quite a number of construction projects faces litigation and researcher suggested method to resolve the construction claims. In a research by Sambasivan (2007), it was found that factors related with contractor and consultant were mainly responsible for delay and cause litigation. The delay in projects had direct impact on project abandonment. Acharya (2006) found that the factors related with contractor and consultant may lead to abandonment of construction projects.

\section{Conclusion}

In this study, eleven factors related with causes of delay and their effects on construction projects of Pakistan were hypothesized and analyzed. Data of 37 construction companies of Pakistan was collected and investigated. Various statistical tools were applied to analyze the data. The significant positive impact of client, material, consultant, and equipment was found on the delay of construction projects of Pakistan. Whereas, general and labor related factors had insignificant effects on delays of construction projects. Moreover, it was found that contractor related causes of delay ranked the highest, which created conflict with other stakeholders of construction projects. Likewise, cost overrun was ranked highest among the effects of delays in construction projects of Pakistan. The results are partially aligned, strengthened, and confirmed the results of previous similar researches.

\subsection{Implications}

The firms can build strategies in managing construction projects, while focusing on project delay factors and their effects. Based on the analysis, the study suggested the following to construction firms in managing projects: 
- Financial matters should have the highest importance especially when dealing with contractors, and clients.

- Relationship with client during project duration should keep strengthening especially on-time transfer of deliverables and milestones as well as timely update the clients on project progress in order to reduce conflicts.

- Construction companies should analyze the capability of consultant carefully to handle the project and develop good relationship with them

- Attention is needed to handle materials and have sound supply change management in place, which ensure the smooth supply of materials in various project phases.

- Construction firms also focus at moderate level on investing the latest machinery and equipment that help in better execution of construction projects as well as to attract clients with latest technology.

\section{References}

Acharya, N. K., Dai Lee, Y., \& Man Im, H. (2006). Conflicting factors in construction projects: Korean perspective. Engineering, Construction and Architectural Management, 13(6), 543-566.

Aibinu, A. A., \& Jagboro, G. O. (2002). The effects of construction delays on project delivery in Nigerian construction industry. International journal of project management, 20(8), 593-599.

Al-Khalil, M. I., \& Al-Ghafly, M. A. (1999). Delay in public utility projects in Saudi Arabia. International Journal of Project Management, 17(2), 101-106.

Al-Kharashi, A., \& Skitmore, M. (2009). Causes of delays in Saudi Arabian public sector construction projects. Construction Management and Economics, 27(1), 3-23.

Arditi, D., \& Pattanakitchamroon, T. (2006). Selecting a delay analysis method in resolving construction claims. International Journal of Project Management, 24(2), 145-155.

Assaf, S. A., \& Al-Hejji, S. (2006). Causes of delay in large construction projects. International Journal of Project Management, 24(4), 349-357.

Baldwin, J. R., Manthei, J. M., Rothbart, H., \& Harris, R. B. (1971). Causes of delay in the construction industry. Journal of the Construction Division, 97(2), 177-187.

Browne, M. W., \& Cudeck, R. (1993). Alternative ways of assessing model fit. Sage focus editions, 154, 136-136.

Chou, J. S., \& Yang, J. G. (2012). Project management knowledge and effects on construction project outcomes: An empirical study. Project Management Journal, 43(5), 47-67.

Deng, X., Pheng, L. S., \& Zhao, X. (2014). Project system vulnerability to political risks in international construction projects: the case of Chinese contractors. Project Management Journal, 45(2), 20-33.

Doloi, H. (2012). Cost overruns and failure in project management: Understanding the roles of key stakeholders in construction projects. Journal of Construction Engineering and Management, 139(3), 267-279.

Eastman, C. M. (2018). Building product models: computer environments, supporting design and construction. CRC press.

Abd El-Razek, M. E., Bassioni, H. A., \& Mobarak, A. M. (2008). Causes of delay in building construction projects in Egypt. Journal of Construction Engineering and Management, 134(11), 831-841.

Haseeb, M., Bibi, A., \& Rabbani, W. (2011). Problems of projects and effects of delays in the construction industry of Pakistan. Australian Journal of Business and Management Research, 1(5), 41-50.

Jaafari, A. (2001). Management of risks, uncertainties and opportunities on projects: time for a fundamental shift. International Journal of Project Management, 19(2), 89-101.

Lo, T. Y., Fung, I. W., \& Tung, K. C. (2006). Construction delays in Hong Kong civil engineering projects. Journal of Construction Engineering and Management, 132(6), 636-649.

Maqbool, R., Sudong, Y., Manzoor, N., \& Rashid, Y. (2017). The impact of emotional intelligence, project managers' competencies, and transformational leadership on project success: An empirical perspective. Project Management Journal, 48(3), 58-75.

Maqbool, R., Rashid, Y., Sultana, S., \& Sudong, Y. (2018). Identifying the critical success factors and their relevant aspects for renewable energy projects; an empirical perspective. Journal of Civil Engineering and Management, 24(3), $223-237$.

Marsh, H. W., \& Hocevar, D. (1985). Application of confirmatory factor analysis to the study of self-concept: First-and higher order factor models and their invariance across groups. Psychological Bulletin, 97(3), 562.

Mohamed, N., Ridwan, A., Saoula, O., \& Issa, M. (2019). Factors causing mismanagement in public/private contracts: An Indonesian perspective. Management Science Letters, 9(9), 1429-1438.

Nilashi, M., Zakaria, R., Ibrahim, O., Majid, M. Z. A., Zin, R. M., \& Farahmand, M. (2015). MCPCM: a DEMATEL-ANPbased multi-criteria decision-making approach to evaluate the critical success factors in construction projects. Arabian Journal for Science and Engineering, 40(2), 343-361.

Neter, J., Wasserman, W., \& Kutner, M. H. (1989). Applied linear regression models.

Odeh, A. M., \& Battaineh, H. T. (2002). Causes of construction delay: traditional contracts. International Journal of Project Management, 20(1), 67-73.

Rahsid, Y., Haq, S., \& Aslam, M. (2013). Causes of delay in construction projects of Punjab-Pakistan: An empirical study. Journal of Basic and Applied Scientific Research, 3(10), 87-96.

Rashid, M. R. (2017). Detrimental changes and construction projects: need for comprehensive controls.

Sambasivan, M., \& Soon, Y. W. (2007). Causes and effects of delays in Malaysian construction industry. International Journal of Project management, 25(5), 517-526. 
Shaikh, A. W., Muree, M. R., \& Soomro, A. S. (2010). Identification of critical delay factors in construction. Sindh University Research Journal-SURJ (Science Series), 42(2).

Shehu, Z., Endut, I. R., Akintoye, A., \& Holt, G. D. (2014). Cost overrun in the Malaysian construction industry projects: A deeper insight. International Journal of Project Management, 32(8), 1471-1480.

Sweis, G., Sweis, R., Hammad, A. A., \& Shboul, A. (2008). Delays in construction projects: The case of Jordan. International Journal of Project Management, 26(6), 665-674.

Tam, C. M., Zeng, S. X., \& Deng, Z. M. (2004). Identifying elements of poor construction safety management in China. Safety science, 42(7), 569-586.

Wang, J., Sun, W., Shou, W., Wang, X., Wu, C., Chong, H. Y., ... \& Sun, C. (2015). Integrating BIM and LiDAR for realtime construction quality control. Journal of Intelligent \& Robotic Systems, 79(3-4), 417-432.

Wei, K. S. (2010). Causes, effects and methods of minimizing delays in construction projects. A project report.

Williams, T. (2003). Assessing extension of time delays on major projects. International Journal of Project Management, 21(1), 19-26.

Yang, J. B., \& Wei, P. R. (2010). Causes of delay in the planning and design phases for construction projects. Journal of Architectural Engineering, 16(2), 80-83.

Zaneldin, E. K. (2006). Construction claims in United Arab Emirates: Types, causes, and frequency. International Journal of Project Management, 24(5), 453-459.

Zhu, G., Bard, J. F., \& Yu, G. (2005). Disruption management for resource-constrained project scheduling. Journal of the Operational Research Society, 56(4), 365-381.

\section{Appendix}

Research questionnaires and factor analysis

\begin{tabular}{|c|c|c|}
\hline Variables & Item Statements & Factor loading \\
\hline \multirow[t]{8}{*}{ Related with contractor } & - Rework because of errors in construction & 0.57 \\
\hline & - Conflicts in project execution due to sub-contractor schedule & 0.46 \\
\hline & - Conflict between other parties and contractor & 0.42 \\
\hline & - Implementation of improper methods of construction & 0.53 \\
\hline & - Delays in sub-contractor work & 0.48 \\
\hline & - Delays due to site mobilization & 0.59 \\
\hline & - Technical staff qualification is not appropriate & 0.58 \\
\hline & - Numerous replacements of sub-contractor & 0.55 \\
\hline \multirow[t]{6}{*}{ Related with Client } & - Change in order by the owner during construction & 0.40 \\
\hline & - Delay in approving or revising design documents & 0.43 \\
\hline & - Late in final approval of material and shop drawing & 0.69 \\
\hline & - Lack in coordination and communication & 0.68 \\
\hline & - Slow in making decisions & 0.66 \\
\hline & - Conflict in joint-ownership of the project & 0.56 \\
\hline \multirow[t]{4}{*}{ Related with Consultant } & - Consultant experience inadequate & 0.68 \\
\hline & - Poor coordination and communication & 0.66 \\
\hline & - Delay in producing design document & 0.55 \\
\hline & - Details of drawing unclear & 0.63 \\
\hline \multirow[t]{4}{*}{ Related with material } & - Changes in types of material in construction & 0.61 \\
\hline & - Delay in delivery of material & 0.63 \\
\hline & - Delay in producing distinctive building materials & 0.67 \\
\hline & - Late procurement of materials & 0.67 \\
\hline \multirow[t]{5}{*}{ Related with Equipment } & - Breakdowns in equipment & 0.60 \\
\hline & - Shortage of proper equipment & 0.62 \\
\hline & - Low level of equipment handling skill & 0.57 \\
\hline & - Lack in productivity and equipment efficiency & 0.64 \\
\hline & - Lack of mechanical equipment with high-technology & 0.63 \\
\hline \multirow[t]{3}{*}{ Related with Labor } & - Labor shortage & 0.69 \\
\hline & - Low level Labor productivity & 0.55 \\
\hline & - Conflict of personal opinion among labors & 0.58 \\
\hline \multirow[t]{4}{*}{ Related with general factor } & - Effect of weather on construction & 0.64 \\
\hline & - Accident occurs during construction & 0.52 \\
\hline & - Delay in final inspection & 0.49 \\
\hline & - Delay in getting permit & 0.53 \\
\hline Related with Delay & - Delay occurred (percentage) in all delayed projects & 0.69 \\
\hline \multirow[t]{2}{*}{ Related with Cost overrun } & - Accuracy in initial cost estimate & 0.46 \\
\hline & - Cost overrun (percentage) in all projects & 0.67 \\
\hline \multirow[t]{2}{*}{ Related with Time Overrun } & - Number of projects faced time overrun & 0.49 \\
\hline & - Time overrun (percentage) in all projects & 0.77 \\
\hline \multirow[t]{2}{*}{ Related with Litigation } & - Number of projects faced litigation & 0.79 \\
\hline & - Litigation (percentage) faced in all projects & 0.52 \\
\hline \multirow[t]{2}{*}{ Related with Abandonment } & - Number of projects abandoned & 0.79 \\
\hline & - Abandonment (percentage) during all projects & 0.70 \\
\hline
\end{tabular}


(C) 2020 by the authors; licensee Growing Science, Canada. This is an open access article distributed under the terms and conditions of the Creative Commons Attribution (CC-BY) license (http://creativecommons.org/licenses/by/4.0/). 